\title{
Effects of Regional Bank Merger on Small Business Borrowing: Evidence from Japan
}

\author{
Hironobu Miyazaki ${ }^{1} \&$ Hiroyuki Aman ${ }^{2}$ \\ ${ }^{1}$ School of Economics, Nanzan University, Nagoya, Japan \\ ${ }^{2}$ School of Business Administration, Kwansei Gakuin University, Nishinomiya, Japan \\ Correspondence: Hironobu Miyazaki, School of Economics, Nanzan University, 18 Yamazato-cho, Showa-ku, \\ Nagoya, Aichi, 466-8673, Japan. Tel: 81-52-832-3111. E-mail: miyahiro@ nanzan-u.ac.jp
}

Received: August 11, 2015

Accepted: August 28, 2015

Online Published: October 25, 2015

doi:10.5539/ijef.v7n11p62

URL: http://dx.doi.org/10.5539/ijef.v7n11p62

\begin{abstract}
This study examines the impact of a regional bank merger in Japan on borrowing by small businesses, focusing on firms that borrow from the acquiring bank, the acquired bank, or both. First, we find that post-merger borrowing costs declined. This result suggests that small borrowers enjoy more favorable post-merger financing conditions because efficiencies from economies of scale lead to lower costs. Second, we find that post-merger borrowing costs decline for firms that borrow only from the acquiring or acquired bank, whereas they did not decline for firms that borrow from both. Third, we find that only small business loans to firms that borrow from both the acquiring and acquired banks decrease post-merger. This result suggests that small business lending might decline because of a merged bank's loan portfolio and lending strategy.
\end{abstract}

Keywords: bank M\&A, regional banking, borrowing costs, small business enterprises, Japan

\section{Introduction}

Since his 2012 re-election, Prime Minister Shinzo Abe has sought to revive Japan's sluggish economy through aggressive monetary easing by the Bank of Japan, massive fiscal stimulus, and structural reforms. To strength local economies, Abe's cabinet and the Financial Services Agency promote consolidations among local banks in a regional banking model resembling that of Europe and North America. Twenty years of mergers have consolidated Japan's city banks into three mega-banks, but the number of regional banks remains high despite mergers and acquisitions (M\&A), causing "over banking" in some areas. The number of bankruptcies among small business enterprises (SBEs) has risen since March 2013 following the expiration of the Small and Medium-Sized Enterprises Financing Facilitation Act. The number of nonperforming loans held by regional banks also has risen, the competition rate among lenders intensifies, and Japan's greying population and declining birth rate complicate attracting borrowers. Consequently, Japan's regional banks face challenging conditions as Abe's government promotes their consolidation, and further widespread reorganization of regional banks is expected.

European and American regional banks have consolidated steadily since 1990, and researchers have widely examined the effects. Sapienza (2002) reached three conclusions regarding the effects of Italian bank mergers on business borrowers. First, if mergers occurred between banks operating in the same province (in-market mergers), post-merger borrowers from the consolidated bank paid significantly lower interest rates. Second, borrowers with multiple banking relationships had access to broader external sources of finance and were unaffected by merger activity. Third, newly merged banks reduced lending to SBEs.

Using proprietary data for US commercial banks, Erel (2011) found significant reductions in spreads for small loans following mergers. This implies that small borrowers pay lower interest rates after banks expanded through mergers. Unlike Sapienza (2002), Erel (2011) found that acquiring banks increase lending to SBEs after M\&A.

Extensive research investigates M\&A among European and North American regional banks, but no scholarly consensus has formed about its effects on business lending. Some studies highlighted its positive effects (Peek \& Rosengren, 1998; Focarelli \& Panetta, 2003; Avery \& Samolyk, 2004; Panetta, Schivardi, \& Shum, 2009). Other studies accentuated its negative effects (Berger, Saunders, Scalise, \& Udell, 1998; Prager \& Hannan, 1998; Bonaccorsi di Patti \& Gobbi, 2001, 2007; Scott \& Dunkelberg, 2003; Calomiris \& Pornrojnangkool, 2005; 
Garmaise \& Moskowitz, 2006; Craig \& Dinger, 2009; Degryse, Masschelein, \& Mitchell, 2010).

Scant research has investigated M\&A among Japanese banks. Shin, Fraser, and Kolari (2003) examined the 1999 Mizuho merger between the Industrial Bank of Japan, Dai-ichi Kangyo Bank, and Fuji Bank to investigate whether consolidation affected bank-firm relationships. Their event study methodology revealed that stock prices of all firms that had borrowed from the acquiring banks declined following the merger. However, declines were significantly less among firms that used one of the three as their main bank or had large credit exposure with one. Uchino and Uesugi (2012) suggested that Japan's largest bank merger-Bank of Tokyo-Mitsubishi and UFJ Bank in 2005-engendered higher borrowing costs partly through exogenous reduction in the number of firm-bank relationships and partly from changes in the acquired bank's organizational structure, including consolidation of branch networks. Ogura and Uchida (2013) found that small bank mergers impair bankers' acquisition of soft information about borrowers (Note 1). This suggests that mergers complicate managerial structures and hinder acquisition and maintenance of soft information among small banks.

To our knowledge, only the aforementioned three studies examine the impact of Japanese bank M\&A on SBE borrowers. Our study differs from these studies in two respects. First, Shin et al. (2003) and Uchino and Uesugi (2012) analyzed how megabank mergers affect comparatively larger and well-established corporate borrowers. These borrowers likely are less dependent on indirect financing, whereas small unlisted firms-i.e., most regional businesses - lack easy access to capital markets and likely depend on bank borrowing. We employ a unique dataset of small, unlisted firms to more accurately observe the effects of a landmark regional bank consolidation. Our study offers the literature's first empirical insights into the effects of regional bank consolidation in Japan.

Second, Ogura and Uchida (2013) surveyed SME characteristics only once and only for 2005. Our analysis extends to periods following the merger, using time-series financial data. By considering differences between pre- and post-merger parameters, we directly measure its long-run effect.

Global studies on banking consolidation employ firm-bank matched panel data to analyze interest rates that consolidating banks charge corporate borrowers for credit lines. We could not employ such a dataset due to the paucity of interest rate data in Japan, a difficulty that may explain why few studies investigate the impact of Japanese bank M\&A on borrowers. We could not isolate interest rates on individual loans from different borrowers, including the post-merger consolidated bank, and firms can borrow from non-merged banks in their market, making it difficult to gauge the effects of mergers on borrowers. Therefore, we sampled firms that borrowed only from the acquiring bank, the acquired bank, and both. We investigate the impact of the merger more precisely using this set of firms. In this respect, our study contributes to the literature of bank M\&A.

This study is structured as follows. Section 2 discusses the theoretical background. Section 3 presents the dataset, model, and results of cross-sectional analysis. Section 4 summarizes and concludes the study.

\section{Theoretical Background}

Theoretical literature posits that bank M\&A exerts positive and negative effects on corporate borrowers through loan rates and quantity of lending. Therefore, we investigate the positive effects of lower borrowing costs through efficiency gains from economies of scale and scope and the negative effects when banks exercise market power to charge corporate borrowers higher rates. M\&A also might engender higher borrowing costs if merged banks persuade government to maintain their dominant market positions. Moreover, newly merged banks might be excessively large and complex, generating higher costs through losses of efficiency and soft information.

Hypothesis 1: Efficiency gains after a merger might produce favorable financing conditions for SBEs. Alternatively, lending conditions might worsen if mergers raise banks' costs or credit market concentration.

We investigated the relationship between borrowing costs and the number of banks from which each SBE in our dataset borrowed. Diamond (1984) showed that borrowing from a single bank is advantageous because it entails lower monitoring costs. These findings suggest that borrowing from a single bank might reduce monitoring costs and therefore borrowing costs. Alternatively, Peterson and Rajan (1994) showed that firms borrowing from multiple banks pay significantly higher rates in the US. This finding might indicate that the number of banks from which firms borrow is a proxy for their creditworthiness. This implies that banks might not lend additional funds to low-quality firms, forcing them to borrow elsewhere at higher rates. In sum, borrowing costs rise as the number of a firm's lenders increases. Contrary to Peterson and Rajan (1994), however, Harhoff and Körting (1998) did not draw that conclusion for German credit markets.

We formulate Hypothesis 2 to examine the foregoing issues in the Japanese regional credit markets:

Hypothesis 2: Pre-merger firms that borrow from both the acquiring and acquired banks pay higher borrowing 
costs than firms that borrow only from the acquiring or the acquired bank. Moreover, as mergers potentially reduce the number of banks from which firms can borrow, borrowing costs might decline for firms that borrow from both banks.

Third, we investigate whether M\&A affects quantity of lending. This issue relates to the size and composition of banks' loan portfolios, their lending strategies, and other factors. Peek and Rosengren (1998) showed that mergers may promote small business lending if the acquiring bank is small or its portfolio has a larger share of small business loans than the acquired bank. Erel (2011) suggested that post-merger increases in numbers of SBE loans might result from changes in lending technologies, acquiring banks' diversification strategies, and technological improvements (e.g., credit scoring models). Mergers of regional banks may reduce competition. This, in turn, may reduce SBE lending in a manner similar to how competition may prompt SBE lending because competition has the tendency to influence banks to seek more profit opportunities. Berger et al. (1998) decomposed the effects of banking consolidation on shares of SBE lending into one static and three dynamic effects that curtail SBE lending.

We formulate Hypothesis 3 to examine conflicting findings in the literature:

Table 1. List of variables and their definitions

\begin{tabular}{ll}
\hline Variable & Definition \\
\hline $\begin{array}{l}\text { Dependent variables } \\
\text { LOG(r) }\end{array}$ & $\begin{array}{l}\text { Logarithm of borrowing cost (\%) } \\
\text { (interest and discount expenses divided by the sum of long-term loans, short-term loans, and notes } \\
\text { discounted during the previous year) } \\
\text { Loans (short-term and long-term loans) divided by tangible assets }\end{array}$ \\
(LOANS)/ASSETS & Logarithm of sales (thousands of yen) \\
\hline Firms' variables & Ordinary income divided by sales \\
LOG(SALES) & Debt divided by total assets \\
PROFITS/SALES & Long-term loan ratio (long-term loans divided by the sum of short-term and long-term loans) \\
DEBTRATIO & Loans (short-term and long-term loans) divided by the sum of loans of both Shinwa Bank and Kyusyu Bank \\
LOANSRATIO & Logarithm of firm's age \\
(LOANS)/LOANS_TWO & 1 if the firm transacted from both Shinwa Bank and Kyusyu Bank, 0 otherwise. \\
LOG(AGE) & 1 if credit rating of the firm is A, 0 otherwise. \\
BOTH & 1 if credit rating of the firm is C, 0 otherwise. \\
VALUEA & Logarithm of loan rates of Shinwa Bank and Kyushyu Bank \\
VALUEC & The sum of loans of both Shinwa Bank and Kyusyu Bank divided by prefectural GDP \\
\hline Banks' and regional variables & The sum of prefectural loans divided by prefectural GDP \\
LOG(RATE) & \\
LOANS_TWO/GDP & 1 if the year after M\&A (2004-2007), 0 otherwise. \\
LOANS_TOTAL/GDP & \\
\hline Mergers' variables & \\
AFTERM\&A &
\end{tabular}

Table 2. Descriptive statistics of variables

\begin{tabular}{lcccccc}
\hline Variable & Mean & Median & Maximum & Minimum & Std. Dev. & Obs. \\
\hline Dependent variables & & & & & & \\
LOG(r) & 0.970 & 1.069 & 4.121 & -4.782 & 0.963 & 261 \\
(LOANS)/ASSETS & 3.108 & 1.145 & 82.320 & 0.001 & 7.748 & 261 \\
\hline Firms' variables & & & & & & \\
LOG(SALES) & 12.440 & 12.650 & 16.547 & 6.172 & 1.629 & 261 \\
PROFITS/SALES & 0.575 & 0.015 & 91.069 & -20.145 & 6.505 & 261 \\
DEBTRATIO & 0.749 & 0.753 & 2.220 & 0.130 & 0.286 & 261 \\
LOANSRATIO & 0.771 & 0.999 & 1.000 & 0.000 & 0.328 & 261 \\
(LOANS)/LOANS_TWO & 0.0003 & 0.0001 & 0.0090 & 0.0000 & 0.0012 & 261 \\
LOG(AGE) & 3.278 & 3.401 & 4.625 & 0.693 & 0.667 & 261 \\
BOTH & 0.172 & 0.000 & 1.000 & 0.000 & 0.378 & 261 \\
VALUEA & 0.123 & 0.000 & 1.000 & 0.000 & 0.329 & 261 \\
VALUEC & 0.172 & 0.000 & 1.000 & 0.000 & 0.378 & 261 \\
\hline
\end{tabular}




\begin{tabular}{lcccccc}
\hline Banks' and regional variables & & & & & & \\
LOG(RATE) & 1.374 & 1.372 & 1.476 & 1.300 & 0.055 & 8 \\
LOANS_TWO/GDP & 0.240 & 0.248 & 0.285 & 0.191 & 0.030 & 8 \\
LOANS_TOTAL/GDP & 0.576 & 0.559 & 0.672 & 0.517 & 0.047 & 8 \\
\hline $\begin{array}{l}\text { Mergers' variables } \\
\text { AFTERM\&A }\end{array}$ & 0.736 & 1.000 & 1.000 & 0.000 & 0.442 & 261 \\
\hline
\end{tabular}

Hypothesis 3: SBE lending rises after mergers. If acquiring banks are small or their portfolios hold a greater proportion of SBE loans than acquired banks, loans to firms that borrow from both the acquiring and acquired banks increase post-merger.

The next section uses the firm-level dataset to examine these three hypotheses. The list of variables and their definitions are indicated in Table 1.

\section{Empirical Analysis}

\subsection{Methodology}

We focus on the Kyushu region, where a spate of regional bank consolidations has occurred. In addition, we particularly examine Japan's landmark regional bank merger: Shinwa Bank and Kyushu Bank in 2003. We select data from Tokyo Shoko Research, Ltd (TSR) for 150 business borrowers from Tosho Shinyo-Roku (the Kyushu region) that transacted with either or both banks during 2000-2007. Isolating these 150 firms enabled us to analyze the Shinwa-Kyushu merger clearly. This is a unique aspect of our study. Our data are obtained from the TSR-Van2 database that daily updates information for 1.9 million Japanese corporations, including business profiles, financial data, bankruptcy information, and marketing reports. We examined unlisted regional firms.

Table 2 reports descriptive statistics for variables. The upper row (lower row) of Table 3 shows pre-merger data (post-merger data). The mean value of $\log \left(r_{i t}\right)$ declines from 1.141 pre-merger to 0.908 post-merger. The mean value of LOANS $_{i t} /$ ASSETS $_{i t}$ declines from 3.362 pre-merger to 3.017 post-merger. Empirical analysis determined whether the merger affected borrowing costs and quantity of lending.

We divided the 2000-2007 period into pre-merger (2000-2003) and post-merger (2004-2007) subsamples. The post-merger period may seem brief, but bank managers, consultants, researchers, and financial media regard three years as sufficient for a full transition to a post-merger equilibrium (Berger et al., 1998) (Note 2). The audit period for the analyzed firms varies, making it impossible to specify exact yearly data. Therefore, we use pooled ordinary least squares without considering year effects.

Table 3. Descriptive statistics of subsample variables

\begin{tabular}{|c|c|c|c|c|c|c|}
\hline \multicolumn{7}{|l|}{ Before Merger } \\
\hline Variable & Mean & Median & Maximum & Minimum & Std. Dev. & Obs. \\
\hline \multicolumn{7}{|l|}{ Dependent variables } \\
\hline LOG(r) & 1.141 & 1.114 & 3.510 & -0.837 & 0.700 & 69 \\
\hline (LOANS)/ASSETS & 3.362 & 1.141 & 43.853 & 0.043 & 7.827 & 69 \\
\hline \multicolumn{7}{|l|}{ Firms' variables } \\
\hline LOG(SALES) & 12.451 & 12.650 & 16.547 & 7.041 & 1.884 & 69 \\
\hline PROFITS/SALES & 0.906 & 0.035 & 41.487 & -4.222 & 5.265 & 69 \\
\hline DEBTRATIO & 0.766 & 0.818 & 1.335 & 0.174 & 0.215 & 69 \\
\hline LOANSRATIO & 0.771 & 0.998 & 1.000 & 0.000 & 0.316 & 69 \\
\hline (LOANS)/LOANS_TWO & 0.0004 & 0.0001 & 0.0079 & 0.0000 & 0.0014 & 69 \\
\hline LOG(AGE) & 3.318 & 3.401 & 4.625 & 1.792 & 0.659 & 69 \\
\hline ВоTH & 0.232 & 0.000 & 1.000 & 0.000 & 0.425 & 69 \\
\hline VALUEA & 0.159 & 0.000 & 1.000 & 0.000 & 0.369 & 69 \\
\hline VALUEC & 0.188 & 0.000 & 1.000 & 0.000 & 0.394 & 69 \\
\hline \multicolumn{7}{|c|}{ Banks' and regional variables } \\
\hline LOG(RATE) & 1.446 & 1.466 & 1.476 & 1.413 & 0.027 & 69 \\
\hline LOANS_TWO/GDP & 0.272 & 0.270 & 0.285 & 0.269 & 0.005 & 69 \\
\hline LOANS_TOTAL/GDP & 0.640 & 0.643 & 0.672 & 0.621 & 0.018 & 69 \\
\hline
\end{tabular}




\begin{tabular}{|c|c|c|c|c|c|c|}
\hline \multicolumn{7}{|l|}{ After Merger } \\
\hline Variable & Mean & Median & Maximum & Minimum & Std. Dev. & Obs. \\
\hline \multicolumn{7}{|l|}{ Dependent variables } \\
\hline LOG(r) & 0.908 & 1.040 & 4.121 & -4.782 & 1.036 & 192 \\
\hline (LOANS)/ASSETS & 3.017 & 1.149 & 82.320 & 0.001 & 7.737 & 192 \\
\hline \multicolumn{7}{|l|}{ Firms' variables } \\
\hline LOG(SALES) & 12.436 & 12.639 & 16.328 & 6.172 & 1.532 & 192 \\
\hline PROFITS/SALES & 0.456 & 0.013 & 91.069 & -20.145 & 6.905 & 192 \\
\hline DEBTRATIO & 0.743 & 0.732 & 2.220 & 0.130 & 0.307 & 192 \\
\hline LOANSRATIO & 0.771 & 1.000 & 1.000 & 0.000 & 0.333 & 192 \\
\hline (LOANS)/LOANS_TWO & 0.0003 & 0.0001 & 0.0090 & 0.0000 & 0.0012 & 192 \\
\hline LOG(AGE) & 3.264 & 3.401 & 4.625 & 0.693 & 0.671 & 192 \\
\hline ВOTH & 0.151 & 0.000 & 1.000 & 0.000 & 0.359 & 192 \\
\hline VALUEA & 0.109 & 0.000 & 1.000 & 0.000 & 0.313 & 192 \\
\hline VALUEC & 0.167 & 0.000 & 1.000 & 0.000 & 0.374 & 192 \\
\hline \multicolumn{7}{|c|}{ Banks' and regional variables } \\
\hline LOG(RATE) & 1.348 & 1.366 & 1.413 & 1.300 & 0.036 & 192 \\
\hline LOANS_TWO/GDP & 0.229 & 0.248 & 0.269 & 0.191 & 0.026 & 192 \\
\hline LOANS_TOTAL/GDP & 0.553 & 0.559 & 0.621 & 0.517 & 0.030 & 192 \\
\hline
\end{tabular}

First, we estimate the following regression equation for firm i at time t:

$$
\begin{aligned}
& \log \left(r_{i t}\right)=\beta_{0}+\beta_{1}\left(\text { PROFITS }_{i t} / \text { SALES }_{i t}\right)+\beta_{2}\left(\text { DEBTRATIO }{ }_{i t}\right) \\
& +\beta_{3}\left(\text { LOANS }_{i t} / \text { LOANS_TWO }\right)+\beta_{4} \log \left(\text { RATE }_{t}\right)+\beta_{5}\left(\text { LOANSRATIO }_{i t}\right)+\beta_{6} \log \left(A G E_{i t}\right) \\
& +\beta_{7} \text { AFTERM \& } A_{i}+\beta_{8} \text { VALUEA }_{i}+\beta_{9} V_{\text {VALUEC }}+u_{i t}
\end{aligned}
$$

Dependent variable $\log \left(r_{i t}\right)$ is the logarithm of borrowing cost for firm i at time $t$ and is calculated using interest and discount expenses divided by the sum of long-term loans, short-term loans, and notes discounted during the previous year.

Within the framework of Equation (1), Hypothesis 1 yields testable predictions for all coefficients. The main independent variable ( AFTERM \& $A_{i}$ ) equals 1 for 2004-2007 and 0 otherwise. Hypothesis 1 that post-merger financing might favor small borrowers due to efficiency gains implies a negative sign for $\beta_{7}$. The co-hypothesis that conditions worsen if mergers engender higher costs or credit market concentration implies a positive sign for $\beta_{7}$.

To control for variations in borrowing costs, we include demand-side, supply-side, interest rate-specific, merger-related, and firm-specific variables. PROFITS ${ }_{i t} /$ SALES $_{i t}$ and DEBTRATIO ${ }_{i t}$ are demand-side variables. PROFITS $_{i t} /$ SALES $_{i t}$, an indicator of a soundly managed and performing firm, is ordinary income divided by sales. The higher its value, the lower is the interest rate charged by the bank, implying a negative sign for $\beta_{1}$. DEBTRATIO ${ }_{i t}$, a proxy for a firm's fundamental risk characteristics, is calculated as debt divided by total assets. A higher value indicates a riskier firm and a higher interest rate for lending. We expect the sign of $\beta_{2}$ to be positive.

Supply-side variable LOANS $_{i t} / L O A N S_{-}$TWO is calculated as (short-term and long-term) loans $i$ divided by the sum of loans from both Shinwa (the acquiring bank) and Kyusyu (the acquired bank). As loans from the banks increase, rates decline. We expect the sign of $\beta_{3}$ to be negative.

Three interest rate-specific variables control for economy-wide variations in underlying cost of capital. Among the three, $\log \left(R A T E_{t}\right)$ is the core variable, representing the logarithm of loan rates for Shinwa and Kyusyu. Borrowing costs are linked to $\log \left(R A T E_{t}\right)$, suggesting that $\beta_{4}$ has a positive sign. LOANSRATIO it is the ratio of long-term loans calculated as long-term loans divided by the sum of short-term and long-term loans. Borrowing 
costs rise as increases, implying a positive sign for $\beta_{5}$.

The logarithm of a firm's age, $\log \left(A G E_{i t}\right)$ is calculated as the number of years since a firm was established. Young firms generally pay higher rates than established firms. However, lenders might offer younger firms a lower rate to encourage long-term relationships and future borrowing. In such a case, younger firms might pay lower rates than established firms. A negative value for $\beta_{6}$ indicates an inverse relation between age and interest rate; a positive value suggests the opposite.

The regression includes creditworthiness dummies VALUEA and VALUEC. The Tosho Shinyo-Roku report rates firms $\mathrm{A}, \mathrm{B}$, and $\mathrm{C}$, with $\mathrm{A}$ being the highest rating and $\mathrm{C}$ being the lowest. VALUEA and VALUEC equal 1 if a firm's credit is A-rated or C-rated and 0 otherwise.

Second, we examined Hypothesis 2 by estimating the effect of a reduction in the number of banks from which SBEs borrow. Our estimated model has these specifications:

$$
\begin{aligned}
& \log \left(r_{i t}\right)=\beta_{0}+\beta_{1}\left(\text { PROFITS }_{i t} / \text { SALES }_{i t}\right)+\beta_{2}\left(\text { DEBTRATIO }_{i t}\right) \\
& +\beta_{3}\left(\text { LOANS }_{i t} / \text { LOANS_TWO }\right)+\beta_{4} \log \left(\text { RATE }_{t}\right)+\beta_{5}\left(\text { LOANSRATIO }_{i t}\right) \\
& +\beta_{6} \log \left(A G E_{i t}\right)+\beta_{7} A F T E R M \& A_{i}+\beta_{8} \text { BOTH }_{i t}+\beta_{9}\left(\text { BOTH }_{i t} * \text { AFTERM \& } A_{i}\right) \\
& +\beta_{10} V A L U E A_{i}+\beta_{11} \text { VALUEC }_{i}+u_{i t}
\end{aligned}
$$

Alongside independent variables in Equation (1), we include $B O T H_{i t}$ and the interaction variable $B O T H_{i t} * A F T E R M \& A_{i} \cdot B O T H_{i t}$ equals 1 if the SBE had transacted with both Shinwa and Kyusyu and 0 otherwise. A positive value for $\beta_{8}$ supports Hypothesis 2 that firms borrowing from the acquiring and acquired banks pay higher costs than firms that borrow from one or the other. A negative value for $\beta_{9}$ suggests that post-merger costs for SBEs that borrowed from both Shinwa and Kyusyu declined.

To examine Hypothesis 3, we estimate the effect of mergers on quantity of lending. Our basic estimated model has these specifications:

$$
\begin{aligned}
& \text { LOANS }_{i t} / \text { ASSETS }_{i t}=\beta_{0}+\beta_{1} \log \left(\operatorname{SALES}_{i t}\right)+\beta_{2}\left(\text { PROFITS }_{i t} / \text { SALES }_{i t}\right)+\beta_{3} \log \left(r_{i t}\right)
\end{aligned}
$$

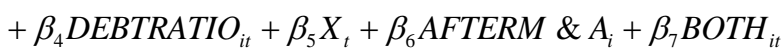

$$
\begin{aligned}
& +\beta_{8} \text { BOTH }_{i t} * \text { AFTERM \& } A_{i}+\beta_{9} \text { VALUEA }_{i}+\beta_{10} \text { VALUEC }_{i}+u_{i t}
\end{aligned}
$$

Dependent variable $\operatorname{LOANS}_{i t} /$ ASSETS $_{i t}$ is calculated as loans (short-term and long-term loans) divided by assets. The main independent variables are $A F T E R M \& A_{i}$ and $B O T H_{i t}$, which are the same as in Equations (1) and (2). According to Hypothesis 3 , a positive coefficient for $\beta_{6}$ implies that post-merger lending increases. A positive value for $\beta_{8}$ suggests that loans to firms borrowing from both Shinwa and Kyusyu increased post-merger.

The logarithm of sales $\left(\log \left(S A L E S_{i t}\right)\right)$ is a proxy for firm size. As it increases, lending to the firm generally increases. Therefore, the expected sign of $\beta_{1}$ is positive. This regression includes PROFITS $_{i t} /$ SALES $_{i t}$, $\log \left(r_{i_{t}}\right)$, DEBTRATIO ${ }_{i t}$, VALUEA, and VALUEC employed in Equations (1) and (2). The higher the value of PROFIT $_{i t} / S_{S A L E}$, the more likely banks are to lend the firm money, implying a positive sign for $\beta_{2}$. As $r_{i t}$ is the borrowing cost for firm i at time t, the expected sign for $\beta_{3}$ is negative.

We expect DEBTRATIO ${ }_{i t}$ to negatively correlate with $\operatorname{LOANS}_{i t} / S A L E S_{i t}$ in Equation (3). However, after Japan's bubble economy burst, some banks lent to deeply indebted firms, particularly in real estate and construction, a practice known as forbearance lending. Although the term has no single definition, Sekine, Kobayashi, and Saita (2003) define it as refinancing a loan (or providing additional credit) even though the borrower likely cannot repay the original amount. Many theoretical models examine motives for forbearance lending, but we believe banks simply hope to prevent the borrower's bankruptcy. If the bank engages in 
forbearance lending, DEBTRATIO ${ }_{i t}$ positively correlates with $\operatorname{LOANS}_{i t} / S A L E S_{i t}$ in Equation (3).

Considering the positive and negative effects of DEBTRATIO ${ }_{i t}$ to $\operatorname{LOANS}_{i t} / S A L E S_{i t}$, we control for nonlinearities of DEBTRATIO $_{i t}$ in the lending relationship. Therefore, we estimate Equation (4) as

$$
\begin{aligned}
& \text { LOANS }_{i t} / \text { ASSETS }_{i t}=\beta_{0}+\beta_{1} \log \left(\text { SALES }_{i t}\right)+\beta_{2}\left(\text { PROFITS }_{i t} / \text { SALES }_{i t}\right)+\beta_{3} \log \left(r_{i t}\right) \\
& +\beta_{4} \text { DEBTRATIO }_{i t}^{2}+\beta_{5} \text { DEBTRATIO }_{i t}+\beta_{6} X_{t}+\beta_{7} \text { AFTERM \& } A_{i}+\beta_{8} \text { BOTH }_{i t} \\
& +\beta_{9} \text { BOTH }_{i t} * \text { AFTERM \& } A_{i}+\beta_{10} \text { VALUEA }_{i}+\beta_{11} \text { VALUEC }_{i}+u_{i t}
\end{aligned}
$$

We also included a vector of $X_{t}$ to control for prefectural economic conditions. This vector comprises the sum of loans by both Shinwa and Kyusyu divided by prefectural GDP and the sum of prefectural loans divided by prefectural GDP. We expect $\beta_{6}$ to be positive.

\subsection{Empirical Results}

Results in Table 4 summarize the estimated coefficients for Equation (1) in our models (Note 3). Columns I and II differ in that column I includes only PROFITS $_{i t} /$ SALES $_{i t}$ as a demand-side variable, whereas column II includes only DEBTRATIO $_{i t}$ as a demand-side variable. Column III includes both. These three regressions include only $\log \left(R A T E_{t}\right)$ as an interest rate-specific variable. In addition, columns IV and V include PROFITS $_{i t} /$ SALES $_{i t}$ and DEBTRATIO ${ }_{i t}$ as demand-side variables. They differ in that column IV includes $\log \left(R_{A T E_{t}}\right)$ and LOANSRATIO $_{i t}$ as interest rate-specific variables, whereas column V includes $\log \left(R_{A T E}\right)$ and $\log \left(A G E_{i t}\right)$ as interest rate-specific variables. Column VI is our preferred specification because it includes all variables.

Estimated coefficients of AFTERM \& $A_{i}$ are negative and statistically significant in all models. These findings endorse those of Sapienza (2002) and Erel (2011), suggesting post-merger borrowing costs declined because efficiency gains create favorable financing conditions for SBEs as per Hypothesis 1.

Estimated coefficients of supply-side variables $L^{2} O A N S_{i t} / L O A N S_{-} T W O_{t}$ are negative and statistically significant in all models, indicating rates declined as borrowing increased.

In columns $\mathrm{V}$ and $\mathrm{VI}$, estimated coefficients of $\log \left(A G E_{i t}\right)$ are positive and significant, implying that older SBEs paid higher rates to banks. This finding contravenes our expectations but endorses those of Peterson and Rajan (1995), who surmise that rural banks seek continuing relationships from small businesses and accept lower returns on initial loans. We identify the effect of rate smoothing on long-term relationships. Findings may be specific to regional markets, which have fewer banks and therefore greater bargaining power that strengthens as borrowers are locked into relationships. Thus, surviving older firms must pay higher rates if they cannot borrow elsewhere. This would explain the positive coefficients of $\log \left(A G E_{i t}\right)$ (Note 4).

In columns IV and VI, estimated coefficients of LOANSRATIO $_{i t}$ are positive and statistically significant in all models. This finding implies that SBEs' borrowing costs rose as long-term loan ratios increased, a finding consist with the theory. Estimated coefficients of $\log \left(R A T E_{t}\right)$ are not statistically significant in any model except in column IV.

Estimated coefficients of VALUEA and VALUEC are negative and statistically significant in all models. These findings imply lower borrowing costs for A-rated and C-rated than for B-rated firms.

Estimated coefficients of demand-side variables PROFITS $_{i t} /$ SALES $_{i t}$ and DEBTRATIO ${ }_{i t}$ are not statistically significant in any model. 
Table 4. Results for Equation (1)

\begin{tabular}{|c|c|c|c|c|c|c|}
\hline \multirow{2}{*}{$\begin{array}{c}\text { Variable } \\
\text { Constant }\end{array}$} & \multicolumn{2}{|l|}{$\mathrm{I}$} & \multicolumn{2}{|l|}{ II } & \multicolumn{2}{|l|}{ III } \\
\hline & 5.248 & $* *$ & 5.167 & $* *$ & 5.260 & $* *$ \\
\hline & $(2.47)$ & & (2.46) & & $(2.47)$ & \\
\hline \multirow[t]{2}{*}{ PROFITS/SALES } & 0.007 & & & & 0.006 & \\
\hline & $(0.01)$ & & & & $(0.01)$ & \\
\hline \multirow[t]{2}{*}{ DEBTRATIO } & & & -0.178 & & -0.167 & \\
\hline & & & $(0.23)$ & & $(0.23)$ & \\
\hline \multirow[t]{2}{*}{ (LOANS)/LOANS_TWO } & -138.957 & $* * *$ & -132.948 & $* * *$ & -132.973 & $* * *$ \\
\hline & $(47.54)$ & & $(48.23)$ & & $(48.28)$ & \\
\hline \multirow[t]{2}{*}{ LOG(RATE) } & -2.711 & & -2.557 & & -2.633 & \\
\hline & $(1.70)$ & & $(1.70)$ & & $(1.71)$ & \\
\hline \multicolumn{7}{|l|}{ LOANSRATIO } \\
\hline \multicolumn{7}{|l|}{ LOG(AGE) } \\
\hline \multirow[t]{2}{*}{ AFTERM\&A } & -0.542 & $* *$ & -0.535 & $* *$ & -0.538 & $* *$ \\
\hline & $(0.21)$ & & $(0.21)$ & & $(0.21)$ & \\
\hline \multirow[t]{2}{*}{ VALUEA } & -0.369 & $* *$ & -0.422 & $* *$ & -0.407 & $* *$ \\
\hline & $(0.18)$ & & $(0.19)$ & & $(0.19)$ & \\
\hline \multirow[t]{2}{*}{ VALUEC } & -0.391 & $* *$ & -0.358 & $* *$ & -0.354 & $* *$ \\
\hline & $(0.16)$ & & $(0.16)$ & & $(0.17)$ & \\
\hline Adj. $R^{2}$ & 0.057 & & 0.057 & & 0.055 & \\
\hline No. of observations & 261 & & 261 & & 261 & \\
\hline Variable & IV & & $\mathrm{V}$ & & $\mathrm{VI}$ & \\
\hline \multirow[t]{2}{*}{ Constant } & 5.124 & $* *$ & 4.160 & $*$ & 4.021 & $*$ \\
\hline & $(2.45)$ & & (2.45) & & $(2.43)$ & \\
\hline \multirow[t]{2}{*}{ PROFITS/SALES } & 0.005 & & 0.005 & & 0.004 & \\
\hline & $(0.01)$ & & $(0.01)$ & & $(0.01)$ & \\
\hline \multirow[t]{2}{*}{ DEBTRATIO } & -0.055 & & -0.235 & & -0.123 & \\
\hline & $(0.23)$ & & $(0.23)$ & & $(0.23)$ & \\
\hline \multirow[t]{2}{*}{ (LOANS)/LOANS_TWO } & -112.003 & $* *$ & -118.400 & $* *$ & -97.264 & $* *$ \\
\hline & $(48.80)$ & & (47.68) & & $(48.16)$ & \\
\hline \multirow[t]{2}{*}{ LOG(RATE) } & -2.824 & $*$ & -2.460 & & -2.652 & \\
\hline & $(1.70)$ & & (1.68) & & $(1.67)$ & \\
\hline \multirow[t]{2}{*}{ LOANSRATIO } & 0.418 & $* *$ & & & 0.420 & $* *$ \\
\hline & $(0.19)$ & & & & $(0.18)$ & \\
\hline \multirow[t]{2}{*}{ LOG(AGE) } & & & 0.273 & $* * *$ & 0.274 & $* * *$ \\
\hline & & & $(0.09)$ & & $(0.09)$ & \\
\hline \multirow[t]{2}{*}{ AFTERM\&A } & -0.551 & $* * *$ & -0.510 & $* *$ & -0.523 & $* *$ \\
\hline & $(0.21)$ & & $(0.21)$ & & $(0.21)$ & \\
\hline \multirow[t]{2}{*}{ VALUEA } & -0.371 & $* *$ & -0.478 & $* *$ & -0.442 & $* *$ \\
\hline & $(0.19)$ & & $(0.19)$ & & $(0.19)$ & \\
\hline \multirow[t]{2}{*}{ VALUEC } & -0.403 & $* *$ & -0.344 & $* *$ & -0.393 & $* *$ \\
\hline & $(0.17)$ & & $(0.16)$ & & $(0.16)$ & \\
\hline Adj. $\mathrm{R}^{2}$ & 0.070 & & 0.087 & & 0.103 & \\
\hline No. of observations & 261 & & 261 & & 261 & \\
\hline
\end{tabular}

Notes. Standard errors are in parentheses.

*** Significant at $1 \%$ level, ** significant at $5 \%$ level, * significant at $10 \%$ level.

Table 5 summarizes estimated coefficients for Equation (2) in our models (Note 5). Columns I and II differ in that Columns I includes only $\operatorname{PROFITS}_{i t} / \operatorname{SALES}_{i t}$ as a demand-side variable, whereas column II includes only $D_{E B T R A T I O}{ }_{i t}$ as a demand-side variable. Column III includes both. These three regressions include only $\log \left(R_{A T E_{t}}\right)$ as an interest rate-specific variable. Columns IV and V include both PROFITS ${ }_{i t} / \operatorname{SALES}_{i t}$ and $D_{E B T R A T I O}$ as demand-side variables. They differ in that column IV includes both $\log \left(R A T E_{t}\right)$ and LOANSRATIO $_{i t}$ as interest rate-specific variables, whereas column $\mathrm{V}$ includes $\log \left(R A T E_{t}\right) \operatorname{and} \log \left(A G E_{i t}\right)$. Column VI is as our preferred specification because it includes all variables. 
We ran regressions adding $B O T H_{i t}$ and the interaction variable $B O T H_{i t} * A F T E R M \& A_{i}$ (Table 5). Estimated coefficients of $B O T H_{i t}$ are positive and statistically significant in all models. These results support Hypothesis 2 that firms which borrow from two banks pay higher rates than firms borrowing from one because concentrated borrowing reduces monitoring and borrowing costs. Alternatively, the number of lenders might be a proxy for firm quality. If so, our findings for Japan echo those of Peterson and Rajan (1994) for the US. Estimated coefficients of $B O T H_{i t} * A F T E R M \& A_{i}$ are not statistically significant in any model. These results contravene Hypothesis 2 and suggest that post-merger borrowing costs of firms that borrow from both Shinwa and Kyusyu did not decline. Estimated coefficients of $A F T E R M \& A_{i}$ are negative and statistically significant in all models.

These results also suggest that borrowing costs of firms that borrow only from one or the other declined.

Estimated coefficients of other variables ( PROFITS $_{i t} /$ SALES $_{i t}$, DEBTRATIO $_{i t}$, LOAN $_{i t} / L_{\text {LOAN_TWO }}$, $\log \left(R_{A T E_{t}}\right), \quad$ LOANSRATIO $_{i t}, \log \left(A G E_{i t}\right)$, VALUEA, and VALUEC $)$ are nearly the same as in Table 4.

Table 6 summarizes estimated coefficients for Equations (3) and (4) in our models (Note 6). Columns I-IV show regression results for Equation (3). Columns V-VIII show regression results for Equation (4). To control for prefectural economic conditions, column I includes the sum of loans from both Shinwa and Kyusyu divided by prefectural GDP, LOANS _TWO $/ G D P_{t}$, whereas column II includes the sum of prefectural loans divided by prefectural GDP, LOANS_TOTAL $L_{t} / G D P_{t}$. In addition to columns I and II, we ran regressions adding $B O T H_{i t}$ and the interaction variable $B O T H_{i t} * A F T E R M \& A_{i}$ in columns III and IV. Estimated coefficients of AFTERM \& $A_{i}$ are not statistically significant in any model. These results contravene Hypothesis 3 that small business loans increase post-merger. Estimated coefficients of $B O T H_{i t}$ are positive and statistically significant in columns III and IV. These results indicate greater lending to firms that borrowed from both Shinwa and Kyusyu than those that borrowed from one or the other. However, estimated coefficients of $B O T H_{i t} * A F T E R M \& A_{i}$ are negative and statistically significant in columns III and IV. These results suggest that post-merger loans to SBEs borrowing from both Shinwa and Kyusyu decreased. Our findings for those firms endorse findings of Sapienza (2002) and Berger et al. (1998) but contradict those of Erel (2011) and Peek and Rosengren (1998). One interpretation of our results is that banks' portfolios and lending strategies call for less SBE lending.

Table 5. Results for Equation (2)

\begin{tabular}{|c|c|c|c|c|c|c|}
\hline Variable & I & & II & & III & \\
\hline Constant & $\begin{array}{l}5.081 \\
(2.42)\end{array}$ & $* *$ & $\begin{array}{l}4.986 \\
(2.42)\end{array}$ & $* *$ & $\begin{array}{l}5.096 \\
(2.42)\end{array}$ & $* *$ \\
\hline PROFITS/SALES & $\begin{array}{l}0.008 \\
(0.01)\end{array}$ & & & & $\begin{array}{l}0.007 \\
(0.01)\end{array}$ & \\
\hline DEBTRATIO & & & $\begin{array}{r}-0.239 \\
(0.22)\end{array}$ & & $\begin{array}{r}-0.225 \\
(0.23)\end{array}$ & \\
\hline (LOANS)/LOANS_TWO & $\begin{array}{r}-162.904 \\
(47.27)\end{array}$ & $* * *$ & $\begin{array}{r}-155.197 \\
(47.82)\end{array}$ & $* * *$ & $\begin{array}{r}-155.454 \\
(47.85)\end{array}$ & $* * *$ \\
\hline LOG(RATE) & $\begin{array}{r}-2.681 \\
(1.68)\end{array}$ & & $\begin{array}{r}-2.487 \\
(1.67)\end{array}$ & & $\begin{array}{r}-2.578 \\
(1.68)\end{array}$ & \\
\hline $\begin{array}{l}\text { LOANSRATIO } \\
\text { LOG(AGE) }\end{array}$ & & & & & & \\
\hline AFTERM\&A & $\begin{array}{r}-0.494 \\
(0.22)\end{array}$ & $* *$ & $\begin{array}{r}-0.483 \\
(0.22)\end{array}$ & $* *$ & $\begin{array}{r}-0.487 \\
(0.22)\end{array}$ & $* *$ \\
\hline BOTH & $\begin{array}{l}0.537 \\
(0.27)\end{array}$ & $* *$ & $\begin{array}{l}0.550 \\
(0.27)\end{array}$ & $* *$ & $\begin{array}{l}0.557 \\
(0.27)\end{array}$ & $* *$ \\
\hline BOTH*AFTERM\&A & $\begin{array}{r}-0.019 \\
(0.32)\end{array}$ & & $\begin{array}{r}-0.029 \\
(0.32)\end{array}$ & & $\begin{array}{r}-0.032 \\
(0.32)\end{array}$ & \\
\hline
\end{tabular}




\begin{tabular}{|c|c|c|c|c|c|c|}
\hline VALUEA & $\begin{array}{r}-0.368 \\
(0.18)\end{array}$ & $* *$ & $\begin{array}{r}-0.439 \\
(0.19)\end{array}$ & $* *$ & $\begin{array}{r}-0.421 \\
(0.19)\end{array}$ & $* *$ \\
\hline VALUEC & $\begin{array}{r}-0.342 \\
(0.16)\end{array}$ & $* *$ & $\begin{array}{r}-0.296 \\
(0.16)\end{array}$ & $*$ & $\begin{array}{r}-0.292 \\
(0.16)\end{array}$ & $*$ \\
\hline Adj. $R^{2}$ & 0.091 & & 0.093 & & 0.091 & \\
\hline No. of observations & 261 & & 261 & & 261 & \\
\hline Variable & IV & & $\mathrm{V}$ & & $\mathrm{VI}$ & \\
\hline Constant & $\begin{array}{l}4.989 \\
(2.41)\end{array}$ & $* *$ & $\begin{array}{l}3.887 \\
(2.39)\end{array}$ & & $\begin{array}{l}3.788 \\
(2.38)\end{array}$ & \\
\hline PROFITS/SALES & $\begin{array}{l}0.006 \\
(0.01)\end{array}$ & & $\begin{array}{l}0.006 \\
(0.01)\end{array}$ & & $\begin{array}{l}0.005 \\
(0.01)\end{array}$ & \\
\hline DEBTRATIO & $\begin{array}{r}-0.128 \\
(0.23)\end{array}$ & & $\begin{array}{r}-0.310 \\
(0.22)\end{array}$ & & $\begin{array}{r}-0.213 \\
(0.23)\end{array}$ & \\
\hline (LOANS)/LOANS_TWO & $\begin{array}{r}-136.391 \\
(48.66)\end{array}$ & $* * *$ & $\begin{array}{r}-142.113 \\
(46.92)\end{array}$ & $* * *$ & $\begin{array}{r}-123.422 \\
(47.69)\end{array}$ & $* *$ \\
\hline LOG(RATE) & $\begin{array}{r}-2.737 \\
(1.67)\end{array}$ & & $\begin{array}{r}-2.414 \\
(1.64)\end{array}$ & & $\begin{array}{r}-2.571 \\
(1.63)\end{array}$ & \\
\hline LOANSRATIO & $\begin{array}{l}0.349 \\
(0.18)\end{array}$ & $*$ & & & $\begin{array}{l}0.343 \\
(0.18)\end{array}$ & $*$ \\
\hline LOG(AGE) & & & $\begin{array}{l}0.305 \\
(0.09)\end{array}$ & $* * *$ & $\begin{array}{l}0.303 \\
(0.08)\end{array}$ & $* * *$ \\
\hline AFTERM\&A & $\begin{array}{r}-0.504 \\
(0.22)\end{array}$ & $* *$ & $\begin{array}{r}-0.430 \\
(0.21)\end{array}$ & $* *$ & $\begin{array}{r}-0.447 \\
(0.21)\end{array}$ & $* *$ \\
\hline BOTH & $\begin{array}{l}0.511 \\
(0.27)\end{array}$ & $*$ & $\begin{array}{l}0.685 \\
(0.26)\end{array}$ & $* * *$ & $\begin{array}{l}0.638 \\
(0.26)\end{array}$ & $* *$ \\
\hline BOTH*AFTERM\&A & $\begin{array}{r}-0.013 \\
(0.32)\end{array}$ & & $\begin{array}{r}-0.153 \\
(0.32)\end{array}$ & & $\begin{array}{c}-0.135 \\
(0.32)\end{array}$ & \\
\hline VALUEA & $\begin{array}{c}-0.389 \\
(0.19)\end{array}$ & $* *$ & $\begin{array}{r}-0.507 \\
(0.18)\end{array}$ & $* * *$ & $\begin{array}{r}-0.476 \\
(0.18)\end{array}$ & $* * *$ \\
\hline VALUEC & $\begin{array}{r}-0.336 \\
(0.16)\end{array}$ & $* *$ & $\begin{array}{r}-0.273 \\
(0.16)\end{array}$ & $*$ & $\begin{array}{r}-0.317 \\
(0.16)\end{array}$ & $* *$ \\
\hline Adj. $R^{2}$ & 0.101 & & 0.132 & & 0.141 & \\
\hline No. of observations & 261 & & 261 & & 261 & \\
\hline
\end{tabular}

Notes. Standard errors are in parentheses.

*** Significant at $1 \%$ level, ** significant at $5 \%$ level, * significant at $10 \%$ level.

Columns V-VIII of Table 6 include DEBTRATIO ${ }_{i t}^{2}$ to capture forbearance lending. As in column I, we include LOANS_TWO ${ }_{t} / G D P_{t}$ in column V, whereas, column VI includes $L O A N S \_T O T A L_{t} / G D P_{t}$. In addition, we ran regressions adding $B O T H_{i t}$ and $B O T H_{i t} * A F T E R M \& A_{i}$ in columns VII and VIII. Estimated coefficients of AFTERM \& $A_{i}$ are not statistically significant in any model. Estimated coefficients of $B O T H_{i t}$ are positive and statistically significant in columns VII and VIII, but for $B_{0 T H_{i t}} * A F T E R M \& A_{i}$ they are negative and statistically significant in columns VII and VIII. Results in columns V-VIII coincide with those in columns I-IV.

Estimated coefficients of $\log \left(r_{i t}\right)$ are negative and statistically significant in columns I-VIII, which is consistent with the theory. Estimated coefficients of DEBTRATIO ${ }_{i t}^{2}$ are not statistically significant in Columns V-VIII, but they are positive and statistically significant for $D E B T R A T I O_{i t}$ in columns I-IV. These results suggest that the merged Shinwa and Kyusyu bank engaged in forbearance lending.

In Columns I-VIII, estimated coefficients of other variables $\left(\log \left(\operatorname{SALES}_{i t}\right)\right.$, PROFITS $_{i t} /$ SALES $_{i t}$, DEBTRATIO $_{i t}^{2}$, $L_{\text {OANS }} /$ LOANS_TWO, LOANS_TOTAL $_{t} / G D P_{t}$, and VALUEA) are not statistically significant. Estimated coefficients of VALUEC are positive and statistically significant only in columns III, IV, and VIII. 
Table 6. Results for Equations (3) and (4)

\begin{tabular}{|c|c|c|c|c|c|c|c|c|}
\hline \multirow{2}{*}{$\begin{array}{l}\text { Variable } \\
\text { Constant }\end{array}$} & \multicolumn{2}{|l|}{ I } & \multicolumn{2}{|l|}{ II } & \multicolumn{2}{|l|}{ III } & \multicolumn{2}{|l|}{ IV } \\
\hline & -14.982 & $* *$ & -15.071 & & -14.422 & $* *$ & -12.735 & \\
\hline & $(6.95)$ & & (11.24) & & $(6.80)$ & & $(11.00)$ & \\
\hline \multirow[t]{2}{*}{ LOG(SALES) } & 0.094 & & 0.101 & & -0.035 & & -0.028 & \\
\hline & $(0.30)$ & & $(0.30)$ & & $(0.29)$ & & $(0.29)$ & \\
\hline \multirow[t]{2}{*}{ PROFITS/SALES } & 0.017 & & 0.014 & & 0.017 & & 0.014 & \\
\hline & $(0.07)$ & & $(0.07)$ & & $(0.07)$ & & $(0.07)$ & \\
\hline \multirow[t]{2}{*}{ LOG(r) } & -2.711 & $* * *$ & -2.687 & $* * *$ & -2.988 & $* * *$ & -2.968 & $* * *$ \\
\hline & $(0.48)$ & & $(0.48)$ & & $(0.47)$ & & $(0.47)$ & \\
\hline \multirow[t]{2}{*}{ LOANS_TWO/GDP } & 15.024 & & & & 11.102 & & & \\
\hline & (20.27) & & & & (19.86) & & & \\
\hline \multirow[t]{2}{*}{ LOANS_TOTAL/GDP } & & & 6.598 & & & & 2.131 & \\
\hline & & & (16.37) & & & & (16.03) & \\
\hline \multicolumn{9}{|l|}{ DEBTRATIO $^{2}$} \\
\hline \multirow[t]{2}{*}{ DEBTRATIO } & 3.873 & $* *$ & 3.806 & $* *$ & 3.149 & $*$ & 3.079 & $*$ \\
\hline & $(1.76)$ & & $(1.76)$ & & $(1.72)$ & & $(1.72)$ & \\
\hline \multirow[t]{2}{*}{ AFTERM\&A } & -0.075 & & -0.154 & & 0.973 & & 0.667 & \\
\hline & $(1.34)$ & & $(1.74)$ & & $(1.42)$ & & $(1.78)$ & \\
\hline \multirow[t]{2}{*}{ BOTH } & & & & & 7.298 & $* * *$ & 7.298 & $* * *$ \\
\hline & & & & & $(2.04)$ & & $(2.04)$ & \\
\hline \multirow[t]{2}{*}{ BOTH*AFTERM\&A } & & & & & -4.795 & $*$ & -4.730 & $*$ \\
\hline & & & & & $(2.46)$ & & $(2.46)$ & \\
\hline \multirow[t]{2}{*}{ VALUEA } & 2.096 & & 2.084 & & 1.626 & & 1.613 & \\
\hline & (1.46) & & (1.46) & & (1.43) & & (1.43) & \\
\hline VALUEC & 1.982 & & 2.048 & & 2.496 & $* *$ & 2.564 & $* *$ \\
\hline & (1.28) & & $(1.28)$ & & $(1.25)$ & & $(1.25)$ & \\
\hline Adj. $R^{2}$ & 0.167 & & 0.139 & & 0.184 & & 0.183 & \\
\hline No. of observations & 261 & & 261 & & 261 & & 261 & \\
\hline Variable & $\mathrm{V}$ & & $\mathrm{VI}$ & & VII & & VIII & \\
\hline Constant & -15.458 & $* *$ & -15.409 & & -14.476 & $* *$ & -12.786 & \\
\hline & (7.13) & & (11.31) & & $(7.00)$ & & (11.08) & \\
\hline LOG(SALES) & 0.090 & & 0.097 & & -0.036 & & -0.029 & \\
\hline & $(0.30)$ & & $(0.30)$ & & $(0.29)$ & & $(0.29)$ & \\
\hline PROFITS/SALES & 0.017 & & 0.014 & & 0.017 & & 0.014 & \\
\hline & $(0.07)$ & & $(0.07)$ & & $(0.07)$ & & $(0.07)$ & \\
\hline LOG(r) & -2.692 & $* * *$ & -2.667 & $* * *$ & -2.986 & $* * *$ & -2.965 & $* * *$ \\
\hline & $(0.48)$ & & $(0.48)$ & & $(0.48)$ & & $(0.48)$ & \\
\hline LOANS_TWO/GDP & 14.778 & & & & 11.081 & & & \\
\hline & (20.32) & & & & (19.91) & & & \\
\hline LOANS_TOTAL/GDP & & & 6.266 & & & & 2.091 & \\
\hline & & & (16.44) & & & & (16.09) & \\
\hline DEBTRATIO $^{2}$ & -0.775 & & -0.785 & & -0.085 & & -0.110 & \\
\hline & $(2.56)$ & & $(2.56)$ & & $(2.50)$ & & $(2.50)$ & \\
\hline DEBTRATIO & 5.340 & & 5.291 & & 3.310 & & 3.287 & \\
\hline & $(5.15)$ & & $(5.15)$ & & $(5.05)$ & & $(5.06)$ & \\
\hline AFTERM\&A & -0.030 & & -0.127 & & 0.978 & & 0.672 & \\
\hline & $(1.35)$ & & $(1.75)$ & & (1.43) & & $(1.79)$ & \\
\hline ВOTH & & & & & 7.295 & $* * *$ & 7.295 & $* * *$ \\
\hline & & & & & $(2.04)$ & & $(2.05)$ & \\
\hline BOTH*AFTERM\&A & & & & & -4.797 & $*$ & -4.732 & $*$ \\
\hline & & & & & $(2.47)$ & & $(2.47)$ & \\
\hline VALUEA & 2.216 & & 2.205 & & 1.640 & & 1.631 & \\
\hline & $(1.52)$ & & $(1.52)$ & & (1.49) & & (1.49) & \\
\hline VALUEC & 2.009 & & 2.076 & & 2.499 & & 2.568 & $* *$ \\
\hline & $(1.28)$ & & $(1.28)$ & & $(2.47)$ & & $(1.25)$ & \\
\hline Adj. $R^{2}$ & 0.138 & & 0.136 & & 0.181 & & 0.180 & \\
\hline No. of observations & 261 & & 261 & & 261 & & 261 & \\
\hline
\end{tabular}

Notes. Standard errors are in parentheses.

*** Significant at $1 \%$ level, ** significant at $5 \%$ level, * significant at $10 \%$ level. 


\section{Conclusion}

This empirical study examined Japan's merger of two regional banks-Shinwa Bank and Kyushu Bank-in 2003. Using data for 150 small businesses that had borrowed only from Shinwa (the acquiring bank), only from Kyusyu (the acquired bank), or from both banks, we examined three hypotheses that bear implications for future regional banking consolidations in Japan. The study documented three findings.

First, we found that SBEs' borrowing costs decreased after the Shinwa-Kyusyu merger. Looking ahead toward future bank consolidations, this result suggests that small business borrowers enjoy more favorable financing conditions post-merger because economies of scale reduce costs through efficiency gains.

Second, SBEs that borrowed from both Shinwa and Kyusyu (pre-merger) paid higher costs than firms that had borrowed from one or the other. This suggests that concentrated borrowing might reduce monitoring and borrowing costs following future consolidations. Alternatively, the number of lenders might be a proxy for the borrower's quality.

Borrowing costs of firms that borrow only from one or the other declined (post-merger); however, borrowing costs of firms that borrow from both did not decline.

Third, we found greater lending to SBEs that borrowed from both Shinwa and Kyusyu than SBEs that borrowed from one or the other. Furthermore, we found that loans to SBEs from both Shinwa and Kyusyu decreased post-merger. Given that observers anticipate continued consolidations among Japan's regional banks, this result suggests that future lending to SBEs might decline because of a merged bank's loan portfolio and lending strategy.

Thus, this study has highlighted the effects of a landmark regional bank consolidation in Japan and discussed the impact on SBE borrowers in the Kyushu region. Despite the study's empirical reliability, further scholarship is warranted before generalizing its results. Nonetheless, it has identified considerations relevant to business, banking, research, and policymakers as future regional bank consolidations unfold.

\section{Acknowledgements}

The authors are grateful for financial support from the Nanzan University Pache Research Subsidy I-A-2 for 2015, I-A-1 for 2011, the Zengin Foundation for Studies on Economics and Finance, and the Japan Society for the Promotion of Science through Grants-in-Aid for Scientific Research (KAKENHI 21730265). The authors benefited from comments by participants at the annual meeting of the Japanese Economic Association at Doshisya University, the Regional Finance Conference at Nagoya University, the annual meeting of the Japan Finance Association at Toyo University, and the Monetary Economic Workshop at Kobe University. The authors would like to thank Enago (www.enago.jp) for the English language review. The authors are responsible for all errors.

\section{References}

Avery, R. B., \& Samolyk, K. A. (2004). Bank consolidation and small business lending: The role of community banks. Journal of Financial Services Research, 25, 291-325. http://dx.doi.org/10.1023/B:FINA.0000020667.29802.1c

Berger, A. N., \& Udell, G. F. (1995). Relationship lending and lines of credit in small finance. Journal of Business, 68, 351-381. Retrieved from http://www.jstor.org/stable/2353332

Berger, A. N., Saunders, A., Scalise, J. M., \& Udell, G. F. (1998). The effects of bank mergers and acquisitions on small business lending. Journal of Financial Economics, 50, 187-229. http://dx.doi.org/10.1016/S0304-405X(98)00036-1

Bonaccorsi di Patti, E., \& Gobbi, G. (2001). The effects of bank consolidation and market entry on small business lending, Banca d'Italia, Tema di discussione, 404. Retrieved from https://www.bancaditalia.it/pubblicazioni/temi-discussione/2001/2001-0404/index.html?com.dotmarketing. htmlpage.language $=1$

Bonaccorsi di Patti, E., \& Gobbi, G. (2007). Winners or losers? The effects of banking consolidation on corporate borrowers. Journal of Finance, 62, 669-695. http://dx.doi.org/10.1111/j.1540-6261.2007.01220.x

Boot, A. (2000). Relationship banking: What do we know? Journal of Financial Intermediation, 9, 7-25. http://dx.doi.org/10.1006/jfin.2000.0282

Calomiris, C. W., \& Pornrojnangkool, T. (2005). Monopoly-creating bank consolidation? The merger of Fleet and Bank Boston. NBER Working Paper, 11351. Retrieved from http://www.nber.org/papers/w11351.pdf 
Craig, B. R., \& Dinger, V. (2009). Bank mergers and the dynamics of deposit interest rates. Journal of Financial Services Research, 36, 111-133. http://dx.doi.org/10.1007/s10693-008-0042-7

Degryse, H., \& Cayseele, P. V. (2000). Relationship lending within a bank-based system: Evidence from European small business data. Journal of Financial Intermediation, 9, 90-109. http://dx.doi.org/10.1006/jfin.1999.0278

Degryse, H., \& Ongena, S. (2005). Distance, lending relationships and competition. Journal of Finance, 601, 231-266. http://dx.doi.org/10.1111/j.1540-6261.2005.00729.x

Degryse, H., Kim, M., \& Ongena, S. (2005). Microeconometrics of Banking: Methods, Applications, and Results. Oxford University Press.

Degryse, H., Masschelein, N., \& Mitchell, J. (2010). Staying, dropping, or switching: The impacts of bank mergers on small firms. The Review of Financial Studies, 24, 1102-1140. http://dx.doi.org/10.1093/rfs/hhp126

Diamond, D. W. (1984). Financial intermediation and delegated monitoring. The Review of Financial Studies, 51, 393-414. http://dx.doi.org/10.2307/2297430

Erel, I. (2011). The effect of bank mergers on loan prices: Evidence from the United States. The Review of Financial Studies, 24, 1068-1101. http://dx.doi.org/10.1093/rfs/hhp034

Farinha, L. A., \& Santos, J. A. C. (2002). Switching from single to multiple bank lending relationships: Determinants and implications. Journal of Financial Intermediation, 11, 124-151. http://dx.doi.org/10.1006/jfin.2001.0328

Focarelli, D., \& Panetta, F. (2003). Are mergers beneficial to consumers? Evidence from the market for bank deposits. American Economic Review, 93, 1152-1172. http://dx.doi.org/10.1257/000282803769206241

Garmaise, M. J., \& Moskowitz, T. J. (2006). Bank mergers and crime: The real and social effects of credit market competition. Journal of Finance, 61, 495-538. http://dx.doi.org/10.1111/j.1540-6261.2006.00847.x

Harhoff, D., \& Körting, T. (1998). Lending relationships in Germany-Empirical evidence from survey data. Journal of Banking and Finance, 22, 1317-1353. http://dx.doi.org/10.1016/S0378-4266(98)00061-2

Houston, J., \& James, C. (1996). Bank information monopolies and the mix of private and public debt claims. Journal of Finance, 51, 1863-1889. http://dx.doi.org/10.1111/j.1540-6261.1996.tb05229.x

Houston, J. F., James, C. M., \& Ryngaert, M. D. (2001). Where do merger gains come from? Bank mergers from the perspective of insiders and outsiders. Journal of Financial Economics, 60, 285-331. http://dx.doi.org/10.1016/S0304-405X(01)00046-0

Ogura, Y., \& Uchida, H. (2014). Bank consolidation and soft information acquisition in small business lending. Journal of Financial Services Research, 45, 173-200. http://dx.doi.org/10.1007/s10693-013-0163-5

Panetta, F., Schivardi, F., \& Shum, M. (2009). Do mergers improve information? Evidence from the loan market. Journal of Money, Credit and Banking, 41, 673-709. http://dx.doi.org/ 10.1111/j.1538-4616.2009.00227.x

Peek, J., \& Rosengren, E. S. (1998). Bank consolidation and small business lending: It's not just bank size that matters. Journal of Banking and Finance, 22, 799-819. http://dx.doi.org/10.1016/S0378-4266(98)00012-0

Peek, J., \& Rosengren, E. S. (2005). Unnatural selection: Perverse incentives and the misallocation of credit in Japan. American Economic Review, 95, 1144-1166. http://dx.doi.org/10.1257/0002828054825691

Peterson, M., \& Rajan, R. (1994). The benefit of lending relationships: Evidence from small business data. Journal of Finance, 49, 3-37. http://dx.doi.org/10.2307/2329133

Peterson, M., \& Rajan, R. (1995). The effect of credit market competition on lending relationships. Quarterly Journal of Economics, 110, 405-443. Retrieved from http://www.jstor.org/stable/2118445

Prager, R. A., \& Hannan, T. H. (1998). Do substantial horizontal mergers generate significant price effects? Evidence from the banking industry. Journal of Industrial Economics, 46, 433-452. http://dx.doi.org/10.1111/1467-6451.00082

Rhoades, S. (1998). The efficiency effects of bank mergers. Journal of Banking and Finance, 22, 273-291. http://dx.doi.org/10.1016/S0378-4266(97)00053-8

Sapienza, P. (2002). The effects of banking mergers on loan contracts. Journal of Finance, 57, 329-367. http://dx.doi.org/10.1111/1540-6261.00424 
Scott, J. A., \& Dunkelberg, W. C. (2003). Bank mergers and small firm financing. Journal of Money, Credit and Banking, 35, 999-1017. Retrieved from http://www.jstor.org/stable/3649868

Sekine, T., Kobayashi, K., \& Saita, Y. (2003). Forbearance lending: The case of Japanese firms. Monetary and Economic Studies, 21, 69-92. Retrieved from http://www.imes.boj.or.jp/english/publication/mes/fmes.html

Shin, G. H., Fraser, D. R., \& Kolari, J. W. (2003). How does banking industry consolidation affect bank-firm relationships? Evidence from a large Japanese bank merger. Pacific-Basin Finance Journal, 11, 285-304. http://dx.doi.org/10.1016/S0927-538X(03)00025-8

Stein, J. C. (2002). Information production and capital allocation: Decentralized versus hierarchical firms. Journal of Finance, 57, 1891-1921. http://dx.doi.org/10.1111/0022-1082.00483

Uchino, T., \& Uesugi, I. (2012). The effects of a megabank merger on firm-bank relationships and borrowing costs. RIETI Discussion Paper Series, 12-E-022. Retrieved from http://www.rieti.go.jp/jp/publicat

\section{Notes}

Note 1 . The definition of soft information is vague - it indicates information that cannot be directly verified by anyone other than the agent who collected it and is difficult to communicate even within an organization. Attributes such as an entrepreneur's zeal and competence and employee morale cannot be unambiguously documented in a report that a loan officer can show to his superiors. See Stein (2002) and Ogura and Uchida (2013).

Note 2. This squares with Rhoades (1998) and Houston, James, and Ryngaert (2001). In these studies, post-merger cost savings and revenue gains take about three years.

Note 3. Note that although we selected 150 borrowing firms and a sample period between 2000 and 2007, the number of observations is 261 because of some missing data.

Note 4. Similar arguments are presented in studies pertaining to the effects of the duration of the relationship between the lending bank and borrower on the loan rate. Degryse and Cayseele (2000) and Degryse and Ongena (2005) found that the lending rate increases in tandem with the duration of the relationship. In contrast, Berger and Udell (1995) report that the duration of the relationship has a negative effect on the lending rate. Moreover, there are studies that present conflicting findings. For a survey of these findings, see Degryse, Kim and Ongena (2009).

Note 5. Following Degryse and Cayseele (2000), we attempted to address the potential simultaneity problem between $\log \left(r_{i t}\right)$ and independent variables. As shown in Tables 4 and 5, deleting one independent variable (for instance, PROFITS ${ }_{i t} /$ SALES $_{i t}$ ) does not affect the estimates of other variables. These results suggest that simultaneity problems in our estimated Equations (1) and (2) are minimal.

Note 6. In the same manner as Equations (1) and (2), we attempted to address the potential simultaneity problem between LOANS $_{i t} /$ ASSETS $_{i t}$ and independent variables. Deleting $\log \left(r_{i t}\right)$ does not affect the estimates of other variables, which is not reported in this study. From these results, we believe that simultaneity problems in our estimated Equations (3) and (4) are minimal.

\section{Copyrights}

Copyright for this article is retained by the author(s), with first publication rights granted to the journal.

This is an open-access article distributed under the terms and conditions of the Creative Commons Attribution license (http://creativecommons.org/licenses/by/3.0/). 